\title{
The biotech sector's clarion call for cash
}

Successful Since joining the research ranks on Wall Street 11 years ago, we have witnessed the ups and downs of stock-price performances for the biotechnology industry and the successes and failures of numerous business strategies and companies. We've seen hot initial-public-offering markets when analysts thought that they were smart and biotech chief executive officers (CEOs) thought that they were smarter. We've seen the down times-in 1984, when Amgen's (Thousand Oaks, CA) stock had fallen to $\$ 4.50$ after going public at $\$ 18$ only 12 months before, and when the industry was in such desperate need for cash that even Chiron (Emeryville, CA) was running on fumes, only to be saved by a $\$ 20$ million cash infusion by CibaGeigy (Basel).

One might therefore surmise that, since the industry has survived the cash crises of 1984 and 1988, in this protracted biobear market, which began in mid-1992, the industry only needs a little more time and some good news to get back on its financial feet.

We think not! As we enter 1995, the biotech industry is markedly different from the 1980s, and importantly, the nature of the capital markets for biotech stocks has changed dramatically in the last 10 years. One major difference in the industry today is the sheer number of companies. Moreover, the industry's scientific foundation has become significantly more diverse. This diversity illustrates, on one hand, the scientific richness of the industry and, on the other, the fragmented and potentially fragile scientific underpinnings of many of its companies.

From the standpoint of the capital markets, the importance and influence of institutional investors has expanded dramatically over the past decade. This effect has become particularly prominent in recent years, with the emergence of roughly one dozen dedicated health-care mutual funds. The bull market for the industry in the 1989 1992 timeframe was driven by a positive flow of capital into these funds. Similarly, the poor perfor- mance over the past two years has resulted in a significant net capital outflow from these funds. The ominous aspect for the biotech industry in this scenario is that the portfolio managers of these funds have soured on investing in the industry, except for the select group of commercial biotech companies, favoring, instead, investments in the health care services sector, medical-device companies, and pharmaceutical stocks. Suddenly, as the biotech industry faces yet another cash shortfall, it is competing for institutional capital in a way that it has never had to in the past. Today, the biotech industry must articulate to these institutional buyers why their stocks are more attractive than, for example, the stocks of Schering-Plough (Madison, NJ), Merck (Rahway, NJ), St. Jude Medical (St. Paul, MN), Medtronic (St. Paul, MN), and Humana (Louisville, KY) -a daunting task for even the best of the biotech salesmen/CEOs.

Since the late 1980 s, the venturecapital community and the resulting biotechnology companies they created have focused on building companies based on a combination of a strong technology base and an experienced management team. Borrowing the theme from the popular movie, "Field of Dreams," the pervasive view was that "if we build it, they will come." The "they," in this instance, were the institutional investors with capital. Historically, the critical variables for success in the biotech industry were: technology/product base, people, and capital. We believe that the biotech industryfrom small private companies to established public concerns - will be driven by a single theme in 1995 and beyond: CAPITAL. As a result, the new critical variables for success in biotechnology will be, by priority: capital, people, and technology/product base. Successful companies in the 1995-2000 timeframe will be driven by experienced management teams that can creatively raise and manage the capital to develop a broad technology/product pipeline.

We have always tried to focus on providing "value-added" advice to CEOs in the industry. We strongly believe that the industry-venture capitalists, scientists, executives, and investment bankers - are currently caught in the middle of a "paradigm shift," where the rules of the past do not apply to the future. But no one has figured out the new rules of the game. Therefore, to provide a template for the new strategic gameboard, we offer the following recommendations:

- Don't look back. Recent history for the capitalization of the industry, from 1989 to 1992 , will not be a guide for the future. The capital markets in the U.S. have changed in a fundamental way.

- Access alternative forms of capital. Public companies should recognize the inherent strength in being public and utilize creative means of financing. However, not all public companies are alike. We break these companies down into three sections: commercial concerns, development-stage concerns, and public-venture concerns. The established commercial companies have multiple available capital sources on a worldwide basis. In contrast, the development-stage companies and, in particular, the public-venture companies face a daunting challenge: how to raise capital in an environment where the rules have changed. Our premise is that, for these companies, cash is king. Therefore, focus on private negotiated sources of capital or on strategic alliances for major scientific programs.

- Merge. This would create broader product/technology companies with lower risk profiles. However, this should only occur if the combined entity has the ability to raise additional institutional capital and thereby become stronger.

Our conclusion is straightforward: We are in a new environment where cash is king. Biotech CEOs must now recognize that they must survive to fight another day.

III

Peter Drake is cofounder and executive vice president of Vector Securities International (Deerfield, IL).

Gregory Brown is vice president of Vector Securities International. 